\title{
What Does Belief Have to Do with Truth?
}

\begin{abstract}
I argue that the widely held view that belief aims at the truth is false. I acknowledge that there is an important connection between truth and belief but propose a new way of interpreting that connection. On the account I put forth, evidence of truth constrains belief without furnishing an aim for belief.
\end{abstract}

Keywords: belief, truth, aim of belief, epistemic rationality, epistemic permissibility, doxastic voluntarism

Clearly, the two are somehow connected. There are multiple reasons to think so - for instance, to believe a proposition just is to believe that the proposition is true: you cannot be said to believe $p$ if you think that $p$ is false. In addition, it seems irrational to hold beliefs without evidence, and evidence is needed because it increases the probability of truth. Again, false beliefs strike us as defective on account of being false, in a way in which unsatisfied desires do not strike us as being defective on account of being unsatisfied, presumably because beliefs, but not desires, must represent the world accurately. Last but not least, we cannot acquire any and every belief we please regardless of the evidence we have in support of it, even if there is a tremendous pay-off associated with our acquisition of some unsupported belief.

But what exactly is the connection between truth and belief? On one standard story, inspired by Williams (1973) and at another remove by Anscombe (1957:56), a story further taken up by Searle (1979, 1983), truth is the 'aim' of belief. ${ }^{1}$ Most philosophers accept some version or other of the standard story, ${ }^{2}$ although opinions differ regarding the details: is truth a constitutive aim of the concept of belief so that understanding the concept requires understanding that belief aims at the truth (Boghossian 2003; Shah 2003)? Is it constitutive of the nature of belief, so that no mental attitude counts as a belief unless it aims at the truth (Railton 1994; Velleman 2000; Wedgwood, 2002, 2007)? Does the truth aim govern belief normatively (Gibbard 2005; Millar 2004; Wedgwood 2007, 2013)? Can the truth aim be interpreted in teleological terms, as either a consciously held goal of the believer (Steglich-Petersen 2006) or as a sub-agential goal (Bird 2007)? Does belief have goals in addition to truth, i.e., does it aim at the truth or only at the truth (Whiting 2012, 2013)? Is the goal of belief really truth or some other epistemic good, such as knowledge (Williamson 2002; Owens 2000), understanding (Kvanvig 2004), epistemic virtue (Zagzebski 2004), or justification (Davidson 2000; Rorty 1995; Rosenberg 2002)?

What I would like to do here is argue that despite both its popularity and its initial intuitive appeal, the standard view is false: belief in general cannot be said to 'aim at the truth.' Evidence of truth or falsehood, I will suggest, places constraints on belief, limiting the range of beliefs it is rationally

\footnotetext{
1 It was Williams (1973) who introduced the phrase 'belief aims at the truth,' but Searle's idea that belief has a 'mind-to-world direction of fit,' an idea already to be found in Anscombe (1957:56) though without the label, essentially amounts to the same thing.

2 For dissenting views, see William James (1896/1979) and, more recently, Owens (2003) and Papineau (2013). See also Philip Kitcher (2003: 147-166) for a discussion of subversive truths we may prefer not to know. There are also evolutionary theories according to which the aim of belief is survival. See, for instance, Stich (1990) for discussion.
} 
permissible to hold. But these constraints need not amount to an 'aim.' For considerations of space, I am not going to criticize every permutation of the standard view and will, instead, raise objections to the core idea. In considering possible retorts to the objections I raise, however, I will draw on different versions of the view. Many of the arguments I will present can be used also against theories on which belief has an epistemic aim other than truth.

\section{Some beliefs that don't aim at the truth}

Consider the following:

(1) I believe that there is something good in every human being. ${ }^{3}$

(2) I believe my husband is a very special man in ways in which other men are not.

(3) I believe I will be cured of my illness.

Let us look at the last statement first. Suppose I am gravely ill. And imagine further that I form the belief I will recover from my illness. I form this belief in part because I really want to recover and in part because I think that 'positive thinking' will help, i.e., that I am, in fact, more likely to recover if I manage first to convince myself that I will. Finally, suppose that I do recover against the odds. What was the aim of my belief in my own speedy recovery? It appears to have been speedy recovery. Did my belief achieve its aim? Yes, I think it did. ${ }^{4}$

The other two beliefs on the above list are slightly different both from each other and from the third, but they, like the third, do not appear to aim at the truth. I clearly lack enough evidence to form the belief that there is something good in every human being. I have neither sufficient inductive evidence to conclude that this is the case, nor can I deduce the conclusion from general knowledge about human nature. The second belief does not fare much better. Even if I think reasonably, let us assume - that love puts me in an epistemically privileged position and that because I love my husband, I can see in him admirable qualities that others cannot perceive, ${ }^{5}$ I do not have sufficient evidence to reach my conclusion. For how do I know that, were I to love other people as much as I love him, I would not come to think that others are equally or more special than he is?

One could, perhaps, object to the first two examples on the ground that my beliefs in the specialness of my husband and in the goodness of every human being are not precise enough to count as 'beliefs'. But first, there is some imprecision to many of our beliefs. The question is whether the two

3 This example is reminiscent of Preston-Roedder's 2013 discussion of the belief in human decency. I return to the difference between Preston-Roedder's view and mine at the end.

${ }^{4}$ One could say that if I speedily recover, that makes my belief true. So actually, my belief did aim at its own truth. But of course, this isn't what the tradition means by 'belief aims at truth': the slogan means that belief aims to match an independently existing reality, not that belief aims to bring about its own truth. This is precisely why belief and desire are supposed to have different 'directions of fit.'

${ }^{5}$ Jollimore (2011) argues that love gives us this kind of epistemic advantage. In related discussions, Stroud (2006) advances the thesis that friendship may require epistemic partiality while Keller (2004) contends that being a good friend sometimes requires being epistemically irresponsible. 
in question are so imprecise as to fail to qualify as beliefs. It seems to me that they are not. Consider a close parallel. We all know what it means to say, 'Most 20-year-olds think they are very special,' and many think that 20 -year-olds are wrong to believe this, that really, they are 'nothing special.' But my belief in the specialness of my husband does not seem less precise than the belief in their own specialness that we ascribe to many 20 -year olds. The belief in the goodness of human beings is likewise sufficiently determinate.

\section{Replies in defense of the standard view}

Those who defend the standard view need not give up yet. There are four things they can say in response.

\subsection{These are not really beliefs}

One possibility is to simply deny that the beliefs I list above are, indeed, beliefs. The point here would be not that the propositional content is too imprecise but rather, that I do not really believe it. Perhaps I am just telling myself I believe these things, because I like the idea of those things being true, but I don't really believe they are true. Maybe, I am in a belief-like mental state, but not in a state of belief. A comparison with an ordinary perceptual belief may help illustrate the point. Suppose I believe that there is popcorn on the table. If I am alone in the house, and it somehow turns out that there is no popcorn on the table, I will be surprised and, perhaps, confused to discover that my belief is false. But if, by contrast, I believe that I will recover from my illness, and it turns out I don't recover, I won't be similarly surprised. While in the former case, I am likely to tell myself, 'What happened? I could swear there was popcorn here. Am I losing my mind?' In the latter case I am unlikely to tell myself, 'Die? I never saw that coming.'

Even if this were a good objection, it would lend support only to the descriptive reading of the truth-aim hypothesis, not to the much more widely popular normative reading: it would show only that as a matter of fact, the beliefs in question aim at the truth, not that they should. But I do not think the objection succeeds. I may, indeed, be in a belief-like state. If I am not naturally optimistic and an inner voice keeps telling me that I am never 'among the lucky few' and that I am unlikely to recover, then I may not really have the belief I want to have. However, it may well be that I am in a state of belief. It is the belief in my recovery - rather than some belief-like mental state - which significantly improves my mood, makes me more optimistic, and possibly enhances my prospects of recovery. ${ }^{6}$ I may begin by telling myself I will recover, and it may well be that the positive thoughts go some way toward creating positive affect, perhaps conferring health benefits, but I may succeed in convincing myself, and then I will be in a state of belief. (If I am really lucky, I may not even have to convince myself - it may be that the inner voice tells me that I am usually lucky, and I believe it.)

\subsection{These are beliefs that aim at the truth}

\footnotetext{
${ }^{6}$ Belief-like states may have an impact on my mood - for instance, I may laugh or cry while watching a movie - but these effects are relatively superficial and tend not to linger for very long after the cause of the state, e.g., the film is over.
} 
Perhaps the beliefs I list above are indeed beliefs, but they are also beliefs that aim at the truth. There are two forms this reply can take.

\subsubsection{Doxastic involuntarism to the rescue}

One could argue that they aim at the truth in something like the sense Williams had in mind originally, when he introduced the phrase: they aim to accommodate the evidence, which is why I cannot form beliefs at will. I can perhaps control my inquiry but not its outcome. If I am at a risk for Huntington's disease, for instance, and I don't want to know whether I will get the disease, I'd better not take the test. If I do take the test, I cannot interpret the results in any way I like. This eminently reasonable view of what aspects of the belief formation process are within our voluntary control is, curiously, shared by evidentialists Adler and Hicks (2013), on the one hand, and David Papineau (2013), who denies that belief has an aim, on the other.

If this is all there is to the claim that belief aims at the truth, it does not amount to much. First, even if it were true that we cannot form beliefs at will, our rationality need not be the only obstacle to voluntary belief-formation. Various deeply entrenched biases and other 'mind bugs' may influence our beliefs as well. It is not clear why we should insist that beliefs aim at the truth on account of the rational constraints they are subject to, yet resist saying that beliefs aim to present the world in a way that accords with our biases on account of the constraints that stem from those biases. In fact, my biases may prevent me from reaching the conclusion that seems best supported by the evidence, for example, the conclusion that the country with which my country is at war is no guiltier for the conflict than my country is. ${ }^{7}$ Hence, even if doxastic involuntarism is true, it would not follow from that that the standard view is true.

Second, there are cases in which I succeed in forming a certain belief, not by acquiring new evidence but by directing my attention in particular ways, or even by imagining certain states of affairs in ways that make them seem real and hence probable. For instance, in attempting to acquire a belief in the goodness of every human being, I may deliberately call to mind stories about murderers who were very good and sensitive children, ${ }^{8}$ while in attempting to get myself to believe I will recover from my illness, I may imagine myself healthy on a date in the future that I will only experience if in fact I recover from my illness. Neither of these things has anything directly to do with evidence acquisition. I could transition from a state of not believing that I will recover to a state of believing I will without acquiring any new evidence or making new inferences.

Finally, if we insist that every belief aims at the truth, we may miss a crucial difference between epistemically ideal beliefs acquired purely on the basis of rationally assessing the evidence and beliefs such as the ones I list above, which I will argue in a moment are simply rationally permissible, not epistemically ideal.

\subsubsection{Truth is one of multiple aims beliefpossesses}

\footnotetext{
7 Adler and Hicks (2013: 159) quote Cohen (2000:9) making the closely related point that many of our most important political and religious beliefs are an accident of birth - we have them simply because we were born at a particular time in a particular place.

${ }^{8}$ See Watson 2004.
} 
Another response would be this: the beliefs I list aim at the truth, but they have other aims in addition. The problem with this response is that there is a weaker thesis that captures the intuition behind the response just as well, and there is no reason to espouse a stronger thesis when a weaker one suffices. The weaker view is that evidence of truth serves as a constraint on belief. And evidence clearly does constrain belief. For instance, I can believe that I will recover, but if I am rational, I cannot form the belief I have already recovered if the evidence unambiguously suggests that I have not, and if I somehow convince myself I have recovered - evidence to the contrary notwithstanding - my belief will be irrational. This is because evidence constrains what it is rationally permissible for me to believe. But it does not follow from this that truth is an aim of belief. Consider an analogy: when I decide to do something, laws impose constraints on my deliberative process. I try not to do anything illegal. But it does not follow from this that, for example, when I decide to take a walk, I have one aim to enjoy the weather and another - to do something legal. There may well be occasions on which I do have the aim of staying on 'this' side of the law, for instance, in drafting a contract, but by and large, legal rules constrain my actions without furnishing an 'aim' for them. Or consider another example: plausibly, there is a rationality constraint that preferences must be transitive. But no one claims on this basis that desire aims at transitivity (or practical rationality, or anything else in that neighborhood). ${ }^{9}$ Something similar is true in the case of belief and its connection to truth. Evidence of truth constrains rational belief, and there may be individual beliefs that aim at the truth, but truth cannot be said to be an aim of belief in general.

\subsection{These are defective beliefs}

Another possible response goes like this: while I may have the beliefs I list above, and it may be that they don't aim at the truth, they should, in some sense of 'should': there is something wrong with beliefs that don't aim at the truth. They may be irrational, due to self-deception, unfit to withstand critical scrutiny and practices of justification, etc. This is not necessarily an indictment of the believer: it is quite possible that no one will fault me for acquiring a belief in my own speedy recovery. However, it is an indictment of the belief itself. There is something wrong - epistemically - with these beliefs, even if I have good pragmatic reasons to acquire them. ${ }^{10}$

But is there something wrong with my beliefs? It would be odd to say that my belief in my own speedy recovery, or in the specialness of my husband, or in the goodness of every human being, are irrational or epistemically defective. These beliefs may not be epistemically ideal - and it may well be that we want to call a person disinclined to hold my beliefs in my circumstances 'exceptionally rational' - but they are surely rationally permissible. To argue otherwise would be to postulate an unreasonably high standard of epistemic permissibility, as high as that standard of moral permissibility on which it is impermissible for me to go and buy a cup of coffee, because I could send the money to Oxfam, instead. For just as an action may be morally permissible without having a moral aim, so a belief may be rationally permissible without aiming at the truth.

\footnotetext{
${ }^{9}$ I thank Mike Huemer for this point.

10 This is the strategy taken by Preston-Roedder (2013) in his discussion of the belief in the fundamental decency of human beings. Preston-Roedder contends that while it may be epistemically irrational to hold this belief, it is morally virtuous to be epistemically irrational in this way.
} 


\subsection{These beliefs are Moore-paradoxical}

There is a final retort I wish to consider: the sorts of beliefs I discuss are Moore-paradoxical. Hence, holding them is irrational. Perhaps, it is epistemically permissible for me to believe, without sufficient evidence, that I will be cured of my illness or that my husband is a very special man. But if, this argument goes, I hold these beliefs and know that I have formed them without sufficient evidence, then my epistemic state would have the form, ' $P$, but I don't have enough evidence that $p$ ' or, 'P, but my evidence suggests that $\sim$ p.' Neither of these is the classical version of Moore's paradox, but both are problematic in just the way Moorean statements are problematic. ${ }^{11}$

I have three things to say in responses. First, in at least some of the cases I have in mind, an agent holding beliefs that don't aim at the truth won't, in fact, know that this is what he or she is doing. I expect that this class of cases will be large enough to bear the brunt of the argument all on its own. But we can go further than that.

Second, and more importantly, in order for a Moore-paradoxical state to arise, an agent must be sufficiently moved both by the evidence that $\mathrm{p}$ and by the evidence that $\sim \mathrm{p}$. If the agent is moved solely by the evidence on one side, there is no Moorean paradox. Suppose, for instance, that while I acknowledge I don't have sufficient evidence for the belief that my husband is special, I am not at all moved by that fact. If I then say, 'I believe my husband is a very special man, but I don't have enough evidence for this,' my statement would be superficially like a Moore-paradoxical one but it won't, in fact, be Moore-paradoxical. Consider an analogy. Imagine I am thoroughly convinced that the external world exists. However, I don't think I have sufficient evidence for this belief: I know that all of my evidence is compatible with a number of skeptical scenarios. If I then say, 'I believe that the external world exists, but I don't have enough evidence for this,' there will be no paradox, despite the Moorean syntax. There won't be a paradox, because I don't have contradictory beliefs one in the existence of the external world, the other - in its non-existence. Nor do I have another pair of contradictory epistemic attitudes, for instance, a belief that $p$ and doubt that $p$. Rather, I have only one belief. I acknowledge that the objective evidence supporting that belief is insufficient, but if I am in no way moved by this fact, no paradox arises. As I argue elsewhere, we sometimes make statements that are seemingly Moore-paradoxical for the purpose of obeying the norms governing assertion. Those norms require that we base our statements about objectively existing states of affairs on objective evidence, not on our own seemings. Consider yet another example. If I am teaching a course on quantum mechanics, I must tell my students there are competing interpretations of the theory, and that 'the jury is still out'. I may, however, hold the firm belief that the Copenhagen interpretation is correct and that the many-worlds interpretation is mistaken. If I then say, 'I believe the Copenhagen interpretation is correct, but my evidence is insufficient', there will be no paradox. ${ }^{12}$

\footnotetext{
${ }^{11}$ Michael Huemer (2007, p. 146) suggests that the following is an instance of a Moore-paradoxical statement: "It is raining, but I have no justification for thinking so.” Cf. Gallois 2007, pp. 166-7; de Almeida 2007, p. 56; Adler and Armour-Garb 2007, pp. 161-2.

${ }^{12} \mathrm{I}$ and my co-author Linda Brakel develop this point in more detail in Fileva \& Brakel, 2018.
} 
Third, and finally, some of the beliefs I discuss may involve a Moorean paradox, but it won't follow from this that they are irrational. Moore-paradoxical statements can sometimes be asserted (or thought) without absurdity or irrationality. In particular, and again as I argue elsewhere, what seems to us to be the case may conflict with what we take the objective evidence to be. If the first-person seeming in such cases is sufficiently compelling, a Moorean belief may be rationally permissible. Consider an example borrowed from Dostoyevsky that I've discussed previously. ${ }^{13}$ In The Brothers Karamazov, an 11-year old boy named Kolya Krasotkin makes up his mind to impress his friends by lying on the train track and waiting for an approaching train. Krasotkin does not desire to be hurt: he has properly measured the distance between the ground and the train, and he knows that if he lies still, the train can't touch him. However, when the train actually passes above him, he faints (though he then manages to persuade his friends that the experience did not frighten him in the least). We can describe Krasotkin's state using Moorean syntax: 'The train can't hurt me, but I don't believe that.' But there is no irrationality here. Surely it would be unreasonable to demand an epistemic agent in Kolya's circumstances - rational but not hyper-rational - to be so responsive to thirdperson evidence as to extinguish any lingering doubt that the train might hurt him or her, however strong the objective evidence in favor of lack of danger may be.

Similar considerations apply to some of the cases I discuss here. The subjective seemings I have that my husband is special or that I will recover from my illness may be so compelling as to make it rationally permissible for me to form beliefs based on those seemings, even when I recognize that the beliefs in question are not sufficiently supported by the objective evidence; indeed, even when the objective evidence moves me also and I, like Kolya Krasotkin, end up in a Moore-paradoxical state.

\section{What does belief have to do with truth?}

I already made a first pass at answering this question in suggesting that evidence of truth constrains belief in much the way laws constrain action. It is now time to discuss the connections between truth and belief in a bit more detail.

There are two sets of constraints on belief formation. First, there are constraints that have to do with what is not up to us: since we are rational, we are hard-wired to respond to evidence, and we cannot, in the usual case, form beliefs at will - we may have to resort to various tricks if we want to form a belief inadequately supported by the evidence. It is considerations along these lines which initially lead Williams to suppose that belief aims at the truth. The observations are important, but they do not establish the conclusion that belief aims at the truth, since as we saw above, it is not only rational constraints but biases as well which influence our belief formation.

The second set of constraints is more important. It has to do with what rationality requires - what we ought to believe if we are rational or what belief ought to be like in order to count as rational, not what we can't help but believe. One of the few critics of the truth-aim theory, David Papineau (2013), argues that the value of truth is merely derivative - on Papineau's reckoning, we ought to

\footnotetext{
13 Fileva \& Brakel, 2018.
} 
form true beliefs when something important hinges on 'getting it right,' but we can relax the standard if nothing important hinges on the matter, for instance, if the issue concerns an unimportant fact about the King of Assyria. ${ }^{14}$ Adler and Hicks respond that we cannot do this, because the normativity of truth is grounded in our practices of justification: others may always ask us for reasons, and when they do, it is not acceptable for us to say that we believe something but have no reason to. Adler and Hicks (2013: 145) write: 'That assertion and belief are legitimately subject to justification-seeking "why" questions is the impetus for our claim that there is a proprietary ethics of belief.' And earlier, 'Considerations that do not speak to the truth of a belief offend against the nature of belief.' (2013:144)

But things are a bit more complicated. We have norms that positively go against demanding evidence in certain cases, indeed, norms that require that we try to instill in others beliefs that are inadequately supported by the evidence. For instance, if I convince myself that I will be cured of my grave illness, you should not demand evidence I will be cured, particularly if you know that my belief is correlated with an increased probability of getting cured. In fact, if you are my doctor, spouse, or mother, you may have to try to persuade me that I will be cured in case I sound too pessimistic.

Yet, one could say that the reasons not to ask for justification are not really considerations that epistemically favor holding the belief. After all, what is appropriate to say depends on various pragmatic considerations. What matters for an account of belief is that I cannot coherently believe a proposition while recognizing that I have non-truth-centered reasons for believing it. That's because non-truth-centered reasons are not really reasons for belief. If I am epistemically rational, I will find myself unable to believe on the basis of such reasons. If I am able to believe on the basis of nontruth centered reasons, then I am simply being irrational, even if it is good to be irrational in this way.

There are two things to note here. First, the non-truth centered influences on belief need not be reasons. They may take the form of psychological and motivational facts, which make me interpret the evidence in one way rather than another. Thus, consider another example. Suppose Dexter has gotten a Ph.D. in history and, after applying for academic jobs repeatedly and after spending a number of years moving from one to another temporary employment, he finally gives up on looking for an academic jobs. Dexter takes up a job as a journalist and does quite well, partly on account of his historical knowledge. He thereby comes to reinterpret his life history and, instead of seeing his lack of success in obtaining academic employment as any kind of failure on his part, he comes to see it as a sign he was really meant for another occupation. He comes to believe that his graduate work in history was but a preparation for the job he actually gets. It is clearly psychological facts such as a desire to interpret his life story in a way that would make his life look like a success which motivates Dexter. What I wish to suggest here is that while on the one hand, this is a sour grapes story since if Dexter had succeeded in finding permanent academic employment, he probably would have never considered leaving it in order to become a journalist, Dexter's newly acquired belief is epistemically permissible. There is a separate question about the possibility of non-evidential reasons for belief, over and above the influence of psychological facts such as those that motivate Dexter's belief. I am

\footnotetext{
${ }^{14}$ Note that Papineau attacks only the normative interpretation of the truth-aim theory, not the descriptive one. He argues only that a "schmelieving" community is possible, not that ours is such a community.
} 
not going to settle that question here. I will note only that the existence of such reasons is not necessary for my case.

Second, epistemic rationality permits such influences, whether or not they come in the form of reasons. If, like Othello, I fall prey to jealousy and acquire the groundless belief that my husband is cheating on me, or else I am a hypochondriac and have the baseless belief that I will die from a sniffle, my beliefs may be epistemically irrational. But my beliefs in the specialness of my husband or in my own speedy recovery are not irrational. Neither is Dexter's belief that his graduate work in history was preparation for journalism irrational or epistemically defective.

What I would like to suggest, then, is that evidence of truth constrains belief, but truth is not the aim of belief. Believing what is rationally permissible for me to believe is a bit like doing what is morally or legally permissible for me to do: there are various moral and legal constraints I have to take into account when I act, but it doesn't follow from this that every permissible action of mine has either a moral or a legal aim. Nor does it follow that my actions must have a moral or a legal aim in order to be morally or legally permissible. Likewise, there are various epistemic constraints I may need to accommodate, as well as some that enter my process of belief formation whether I want them to or not, but it does not follow from this that my belief aims at the truth, nor does it follow that, on pain of epistemic irrationality, it should.

ISKRA FILEVA (iskra.fileva@colorado.edu) is Assistant Professor of Philosophy at the University of Colorado, Boulder. She is currently working on a book manuscript under the title: Reflection without Empathy and Other Essays. Her recent publications include 'Historical Inaccuracy in Fiction', forthcoming in American Philosophical Quarterly and (with Linda Brakel) 'Just Another Article on Moore's Paradox, but We Don't Believe That' published in Synthese.

\section{References}

Adler, J. and B. Armour-Garb. 2007. Moore's paradox and transparency. In Moore's Paradox: New Essays on Belief, Rationality, and the First Person, eds. M. Green and J. N. Williams, 146-162. Oxford: Oxford University Press.

Adler, J. and M. Hicks 2013. Non-evidential reasons to believe. In The Aim of Belief, ed. T. Chan, 14066. Oxford: Clarendon Press.

Anscombe, G.E.M. 1957. Intention. Oxford: Blackwell.

Bird, A. 2007. Justified judging. Philosophy and Phenomenological Research 74(1): 81-110.

Boghossian, P. A. 2003. The normativity of content. Philosophical Issues 13(1): 31-45.

Cohen, G.A. 2000. If You're an Egalitarian, How Come You're So Rich? Cambridge, MA: Harvard University Press.

Davidson, D. 2000. Truth rehabilitated. In Rorty and His Critics, ed. R. Brandom. Oxford: Blackwell. 
de Almeida, C. 2007. Moorean absurdity: an epistemological analysis. In Moore's Paradox: New Essays on Belief, Rationality, and the First Person, eds. M. Green and J. N. Williams, 53-75. Oxford: Oxford University Press.

Engel, P. 2013. In defense of normativism about the aim of belief. In The Aim of Belief, ed. T. Chan, 32-63. Oxford: Clarendon Press.

Fileva, I. and L. Brakel. 2018. Just another article on Moore's paradox, but we don't believe that. Synthese online first version published on February 7, 2018: https://doi.org/10.1007/s11229-0181703-1.

Gallois, André. 2007. Consciousness, reasons, and Moore's paradox. In Moore's Paradox: New Essays on Belief, Rationality, and the First Person, eds. M. Green and J. N. Williams, 165-188. Oxford: Oxford University Press.

Gibbard, A. 2005. Truth and correct belief. Philosophical Issues 15(1): 338-350.

Glüer, K. and A. Wikforss. 2009. Against content normativity. Mind 118: 31-70.

Huemer, M. 2007. Moore's paradox and the norm of belief. In Themes from G. E. Moore: New Essays in Epistemology and Ethics, eds. Susana Nuccetelli and Gary Seay, 142-157. New York: Oxford University Press.

James, W. 1896 [1979]. The will to believe. In The Will to Believe and Other Essays in Popular Philosophy, ed. F. Burkhardt et al., 291-341. Cambridge, MA: Harvard University Press.

Jollimore, T. 2011. Love's Vision. Princeton: Princeton University Press.

Keller, S. 2004. Friendship and belief. Philosophical Papers 33: 329-51.

Kitcher, P. 2003. Science, Truth, and Democracy. Oxford: Oxford University Press.

Kvanvig, J. 2003. The V alue of Knowledge and the Pursuit of Understanding. Cambridge: Cambridge University Press.

Millar, A. 2004. Understanding People: Normativity and Rationalizing Explanation. New York, NY: Oxford University Press.

Owens, D. 2003. Does belief have an aim? Philosophical Studies 115: 283-305.

Papineau, D. 2013. There are no norms of belief. In The Aim of Belief, ed. T. Chan, 64-79. Oxford: Clarendon Press.

Preston-Roedder, R. 2013. Faith in humanity. Philosophy and Phenomenological Research 87: 664-87.

Railton, P. 1994. Truth, reason, and the regulation of belief. Philosophical Issues 5: 71-93.

Rorty, R. 1995. Is truth a goal of enquiry? Davidson vs. Wright. Philosophical Quarterly 45: 281-300.

Rosenberg, J. 2002. Thinking About Knowing. Oxford: Clarendon Press.

Searle, J. 1979. Expression and Meaning. Cambridge: Cambridge University Press. 
Searle, J. 1983. Intentionality. An Essay in the Philosophy of Mind. Cambridge: Cambridge University Press.

Shah, N. 2003. How truth governs belief. Philosophical Review 112: 447-82.

Shah, N. and J.D. Velleman. 2005. Doxastic deliberation. Philosophical Review 114: 497-534.

Steglich-Petersen, A. 2006. No norm needed: On the aim of belief. Philosophical Quarterly 56(225): 499-516.

Stich, S. 1990. The Fragmentation of Reason. Cambridge, MA: MIT Press.

Stroud, S. 2006. Epistemic partiality in friendship. Ethics 116: 498-524.

Velleman, D. 2000. On the aim of belief. In The Possibility of Practical Reason, ed., D. Velleman, 244 281. New York, NY: Oxford University Press.

Watson, G. 2004. Responsibility and the limits of evil: Variations on a Strawsonian theme. In Agency and Answerability: Selected Essays, 256-86. Oxford: Oxford University Press.

Wedgwood, R. 2013. The right thing to believe. In The Aim of Belief, ed. T. Chan, 123-39. Oxford: Clarendon Press. . 2007. The Nature of Normativity. New York, NY: Oxford University Press

Whiting, D. 2012. Does belief aim (only) at the truth? Pacific Philosophical Quarterly 93: 279-300.

Whiting, D. 2013. Nothing but the truth: On the norms and aims of belief. In The Aim of Belief, ed. T. Chan, 123-39. Oxford: Clarendon Press.

Williams, B. 1973. Deciding to believe. In Problems of the Self, 136-51. Cambridge: Cambridge University Press.

Williamson, T. 2002. Knowledge and Its Limits. Oxford: Oxford University Press.

Zagzebski, L. 2004. Epistemic value and the primacy of what we care about. Philosophical Papers 33: 353-77. 